THE WORLD ACCORDING TO PHYSICS 



\section{THE WORLD}

ACCORDING

$T \bigcirc P H Y S I C S$

JIM AL-KHALILI

PRINCETON UNIVERSITY PRESS

PRINCETON AND OXFORD 
Copyright () 2020 by Jim Al-Khalili

Requests for permission to reproduce material from this work should be sent to permissions@press.princeton.edu

Published by Princeton University Press

41 William Street, Princeton, New Jersey 08540

6 Oxford Street, Woodstock, Oxfordshire OX20 1TR

press.princeton.edu

All Rights Reserved

ISBN 978-0-691-18230-8

ISBN (e-book) 978-0-691-20167-2

British Library Cataloging-in-Publication Data is available

Editorial: Ingrid Gnerlich and Arthur Werneck

Production Editorial: Mark Bellis

Text and Cover Design: Chris Ferrante

Production: Jacquie Poirier

Publicity: Sara Henning-Stout and Katie Lewis

Copyeditor: Annie Gottlieb

This book has been composed in Adobe Text and Futura PT

Printed on acid-free paper. $\infty$

Printed in the United States of America

10988765543321 